UDC: $630 * 431.1(497.11) " 1991 / 2010 "$

551.58(497.11)"1991/2010"

COBISS.SR-ID: 227886604

Original research paper

Acta Agriculturae Serbica, Vol. XXI, 41 (2016); 3-15

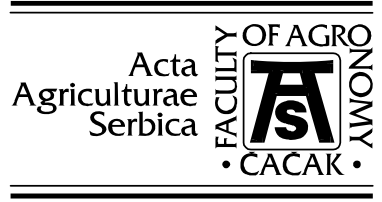

\title{
Monitoring of cloudiness in the function of the forests fire protection
}

\author{
Stanimir Živanović ${ }^{1}$, Darko Zigar ${ }^{2}$ \\ ${ }^{1}$ Emergency Management Sector of Serbia, Belgrade, Serbia, \\ ${ }^{2}$ University of Niš, Faculty of Occupational Safety in Niš, Čarnojevića10a, 18000 \\ Niš, Serbia \\ Correspondingauthor: e-mail:zivannn@mts.rs
}

\begin{abstract}
Fires in forests are seasonal in nature, conditioned by the moisture content of the fuel material. The emergence of these fires in Serbia is becoming more common and depending on the intensity and duration, fires have a major impact on the state of vegetation. The aim of this study was to determine the correlation between dynamics of cloudiness occurrence and forest fires. To study the correlation of these elements, Pearson correlation coefficients were used. The analysis is based on the meteorological data obtained from meteorological station Negotin for the period from 1991 to 2010. Among the tested influences, the degree of cloudiness showed positive correlative interdependence with the dynamics of fire occurrence in nature. The annual number of fires correlates positively with the average number of clear days $(\rho=0.25)$. Also, it was found that the annual number of fires with medium intensity, correlated negatively with the average number of cloudy days $(\rho=-0.26)$, but not statistically significant $(p>0.05)$. Keywords: cloudiness, forest fire, the correlation coefficient.
\end{abstract}

Received: 18.02.2016. Accepted: 10.09.2016. 


\section{Introduction}

Clouds are one of the most important atmospheric phenomena affecting the solar radiation that reaches the Earth's surface. They help in regulating the energy balance of the earth by reflecting and scattering solar radiation, as well as by absorbing the Earth's infrared radiation (Morcrette JJ, 1991). Jakob Christian (Jakob 1998) states that the clouds are important regulators of the climate system. As large reservoirs of latent heat, they have great influence on the atmospheric energy balance (Chevallier et al. 2001).

Cloudiness significantly affects the temperature condition of ground level air, as well as those at higher altitudes, and thus, we can freely say, it controls heating and cooling the surface of the soil and air which is located above it. Increased cloudiness reduces the daily temperature fluctuation of the air (Das et al. 2012). Global radiation strongly modulates cloudiness (Borchert 2005). The process of drying material is directly associated with cloudiness (Zivanovic 2010). If the cloudiness is smaller, the sun-shine duration is longer (Otorepec 1980). The amount of heat received by the vegetation is smaller if the cloudiness is increased, and vice versa. Cloudiness reduces daily maximum temperatures and increases the minimum air temperature at night (Jakob 1998).

Supit and Van Kapel (1998) were based on some earlier researches and they suggested method of estimating the daily sums of global radiation on the basis of the total coverage of clouds during the day and the maximum and minimum daily air temperature (Falayi et al. 2011). Badescu (Badescu et al.2012, Badescu et al. 2015) proposed related solar radiation for clear sky, overcast sky and cloudy sky.

The appearance of clouds is one of the conditions for the existence of many forms of precipitation (Milosavljevic 1990), which is of great importance for the state of vegetation. Precipitation in a specific area affects the humidity of combustible forest materials (Handler et al., 1983) and thus the possibility of ignition and spreading of fire (Curic et al. 2013). Spatial and temporal variability of rainfall in recent decades has become one of the characteristics of climate regions in Negotin.

The ability to accurately show the effects of clouds is of crucial importance not only for meteorology, but also for many other sciences. Quantitative effects of cloudiness on the occurrence of fires in nature are not as developed for the impact of rainfall phenomenon. It is proved that a certain time with a deficit of rainfall, determined by the method of deficit and surplus rainfall, coincide with periods of occurrence of forest fires (Zivanovic et al. 2011). The aim of this study is to determine the interdependence of cloudiness and the risk of forest fires. 


\section{Materials and methods}

Medium level of coverage of the visible part of the sky is determined by cloudiness scale in the range from 0 to 10 . " 0 " is used when the sky is completely clear until " 10 " presents complete coverage of the sky with clouds.

To determine cloudiness the statistics degree of cloudiness and the number of clear and cloudy days at the meteorological station in Negotin were used $\left(\left(\varphi 44^{\circ} 13^{\prime} \mathrm{N} . \lambda 22^{\circ} 31^{\prime} \mathrm{E}\right.\right.$. H=42m)(Figure 1)), during the period from 1991 to 2010. The level of significance $(\mathrm{p}<0.05)$ was determined, we used the $\chi^{2}$ test as a nonparametric method.

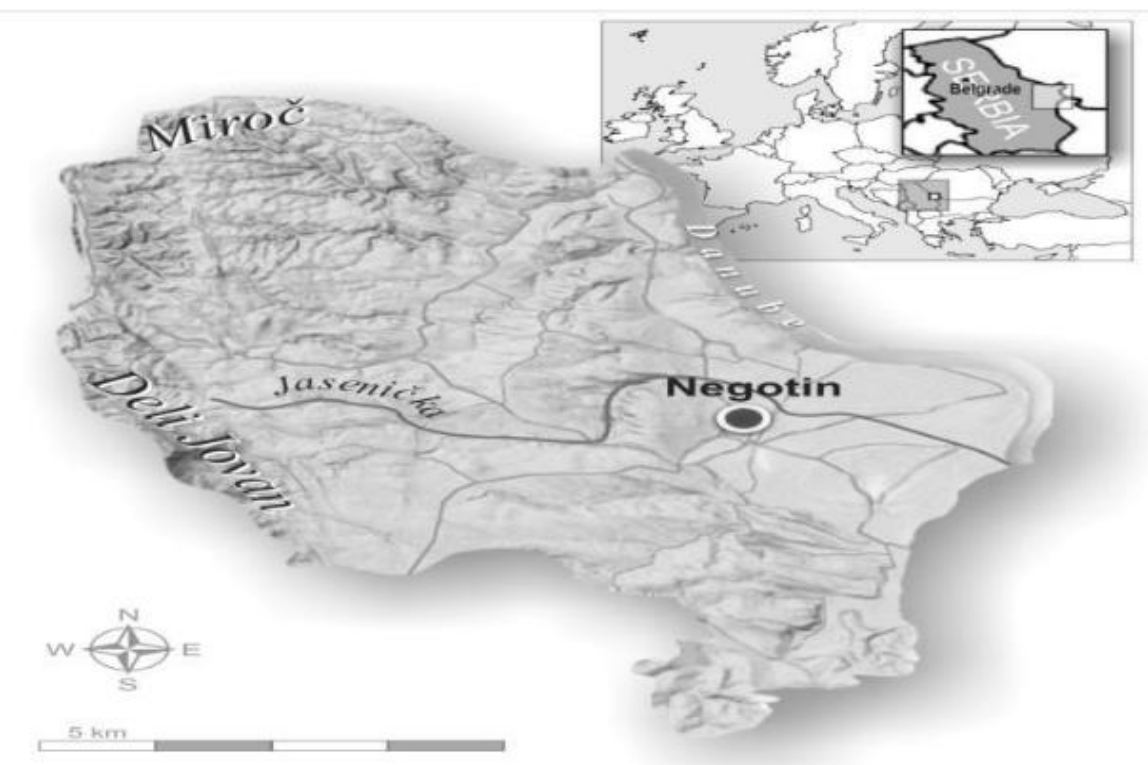

Figure 1. Location of the area of the Negotin municipality

Entry, tabular and graphical presentation of the data was performed using MS Office Excel program, and statistical calculations were performed using the SPSS, version 15.0. Results of statistical analysis are shown graphically.

Normality of distribution parameters were determined by the Shapiro-Wilk test.

By using the Spearman correlation coefficient $-\rho$, the connection between the examined parameters, as well as the significance levels of these correlations were determined. In determining the strength of the correlation for the definition of values of correlation coefficients by Cohen were used (1988): 
- correlation between low level of $0.10-0.29$,

- correlation medium level of $0.30-0.49$,

- high level of correlation $0.50-1.00$.

\section{Main characteristics of cloudiness in Negotin}

Characteristics of the cloudiness in the area of Negotin will be perceived based on the average monthly and yearly level of cloudiness and the number of clear and cloudy days. In figure 2. the values of the average monthly and annual level of cloudiness in a different period are presented (www.hidmet.gov.rs).

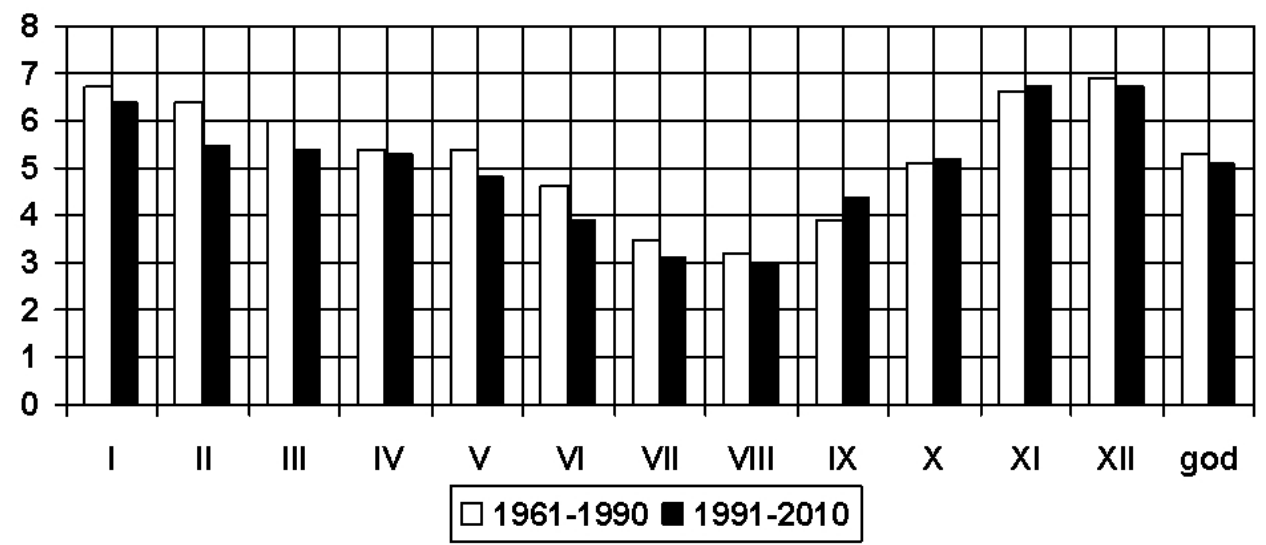

Figure 2. Average monthly and annual cloudiness for different periods analysis of weather station Negotin

According to the average annual value of cloudiness, it can be said that the area of Negotin is more than half cloudy, ie. that the sky during the year is more clouded than clear. The vegetation period Negotin area has an average of 4.1 tenths cloud cover, which is about $80.4 \%$ of the average annual cloudiness. Otherwise, the time the formation of cloudiness in Negotin provides a distinct picture of climate non- homogeneity of the area. The annual flow of cloudiness shows characteristic of continental climate. The value of cloudiness decreases from the beginning of the year and it rises again towards the end of the year. Most intensive cloud cover during the winter period is in December and January. Minimum cloudiness is recorded in August, July and September (Figure 2). Figure 2. shows the reduction in cloud cover on an annual and a monthly basis during the period from 1991 to 2010 compared to the multi-year average values.

Minimum cloudiness in the area of Negotin was registered in 2000 (4.3 tenths) and the highest level of cloudiness was registered in 1996 (5.8 tenths), figure 3 . 


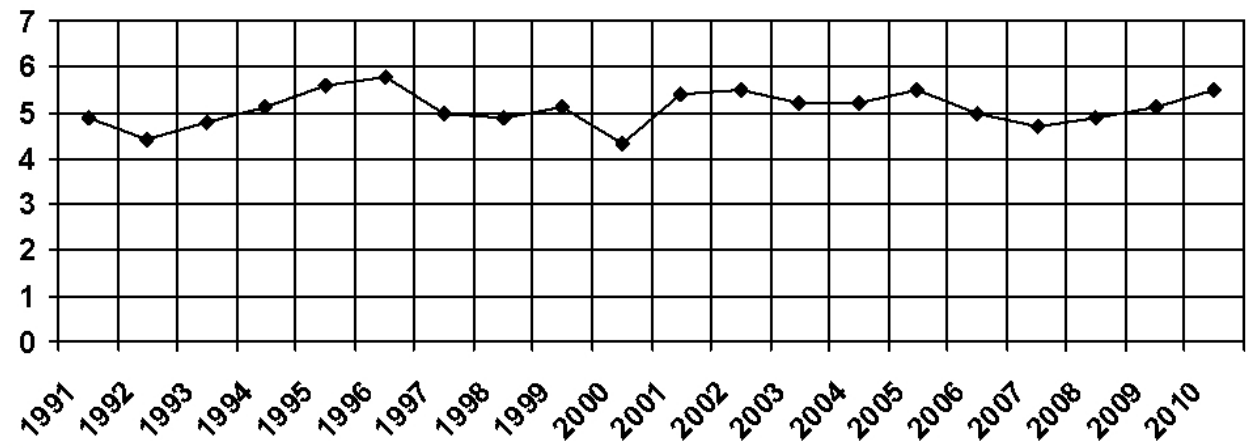

Figure 3. Average annual cloudiness in Negotin in the period from 1991 to 2010 .

Characteristics of cloud cover can be determined by the number of cloudy days during the certain period. The highest values were registered in 1996, 124 even on cloudy days. A minimum value of the number of cloudy days in 2000 , was only 70 days, figure 4 .

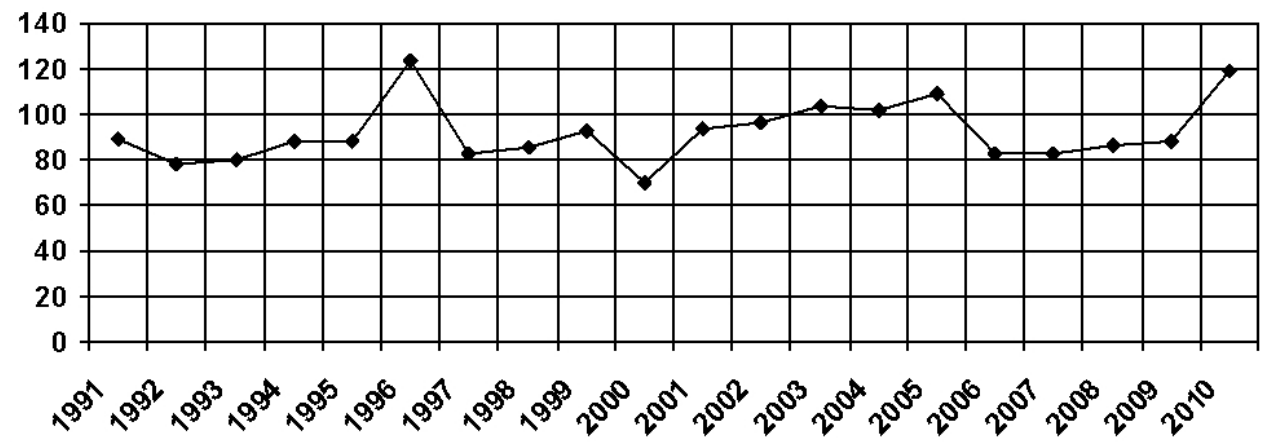

Figure 4. The number of cloudy days in the period from 1991 to 2010.

On a monthly basis the lowest cloudiness is during the months of July and August only 2 days, figure 5. Most cloudy days are during the December (14 days), when the humidity is highest.

For the test period, $(1981 \div 2010)$, locality Negotin average annual number of cloudy days is 94 , which is 16 days less than the perennial average values. 


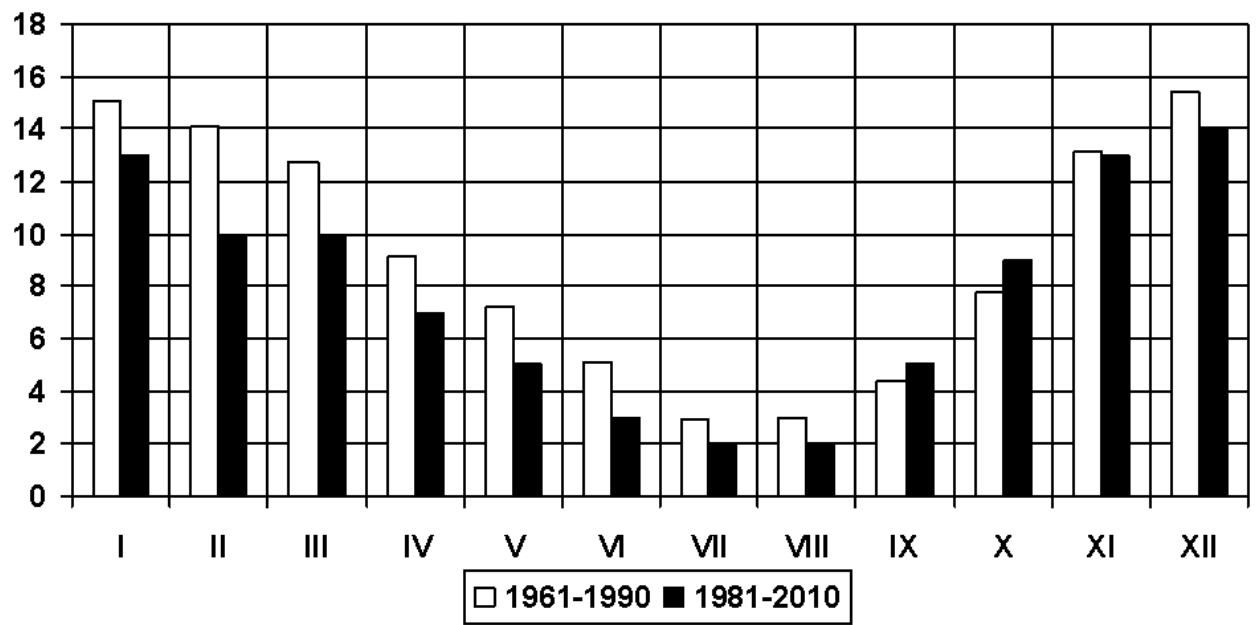

Figure 5. The average monthly number of cloudy days for different periods of analysis for the weather station Negotin.

By reviewing the data for different periods, Figure 5, the reduction of the average number of cloudy days during the growing period and seasons was recorded, excluding the autumn.

Registered decrease in average daily cloudiness is directly reflected on increasing the number of clear days. Looking at the average of the monthly increases, expressed for the first 8 months, and during the growing season, the period $1991 \div 2010$, Figure 6 , it can be concluded that the highest number of clear days occurs in August.

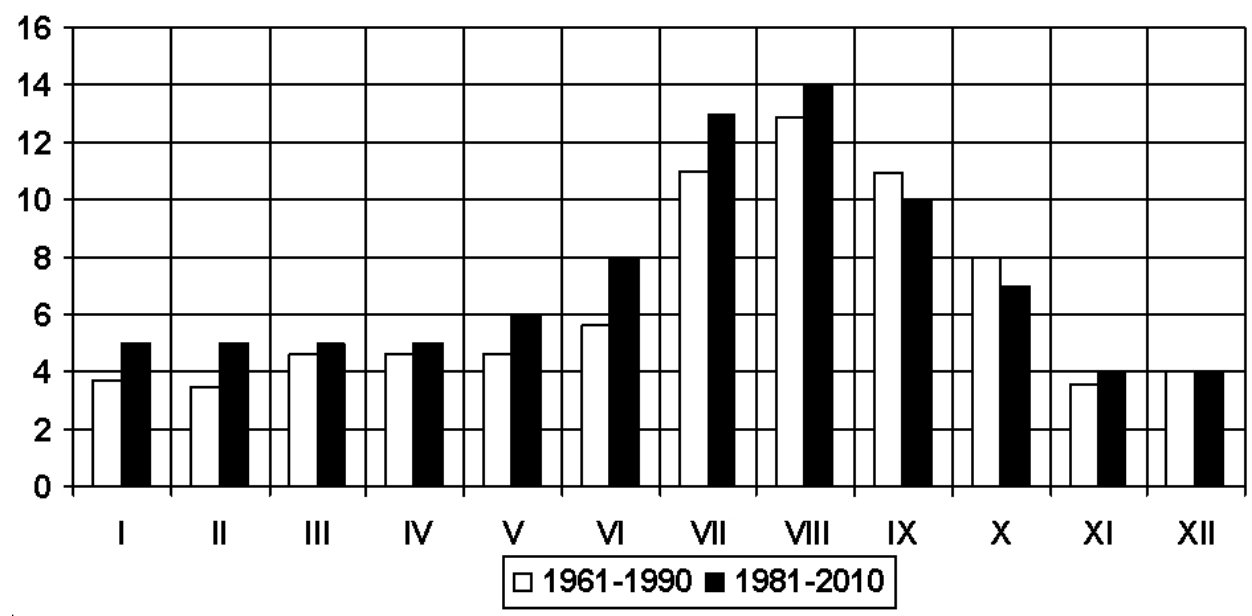

Figure 6. The number of clear days at different periods 
The number of sunny days per annum (87) in the period 1981-2010. was for 10 days higher than in the period 1961-1990, when the average value was 77 clear days. The number of sunny days in Negotin for the period from 1991 to 2010 is shown in Figure 7.

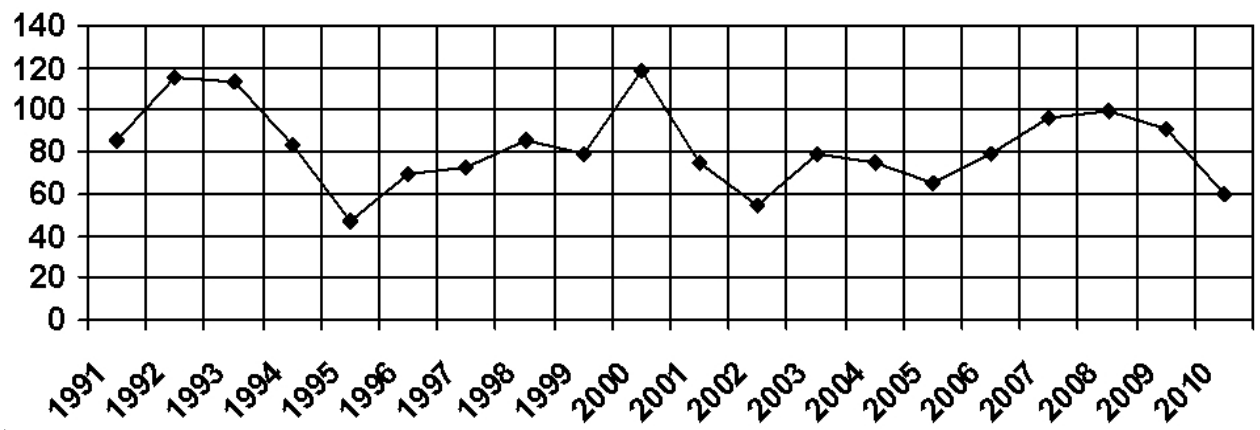

Figure 7. The number of clear days in the period from 1991 to 2010

Figure 6. shows that the biggest number of clear days (119) was in 2000 and the lowest number (47) was in 1995.

\section{Results and discussion}

The dynamics of fire in the municipality of Negotin is different from period to period. Figure 8. shows the number of fires in the open air during the August. The figure shows that the highest number of fires occurred in the open air during the month of August. The minimum number of fire occurrences was during the period of December. At the annual level, the largest number of fires was in the course of 2000 and the lowest was in 2005, Figure 9.

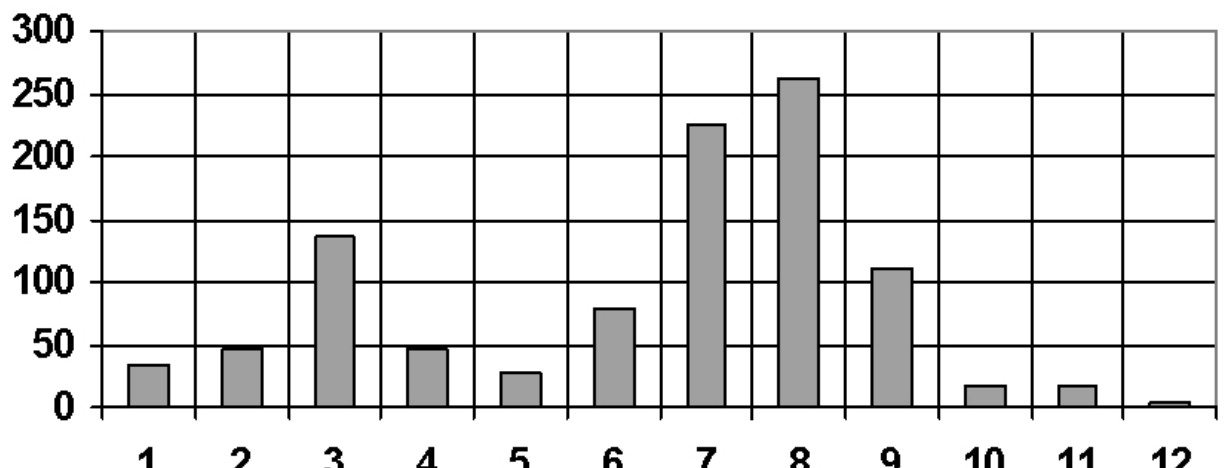

Figure 8. Number of fires in the Municipality of Negotin by months for the period 1991-2010 


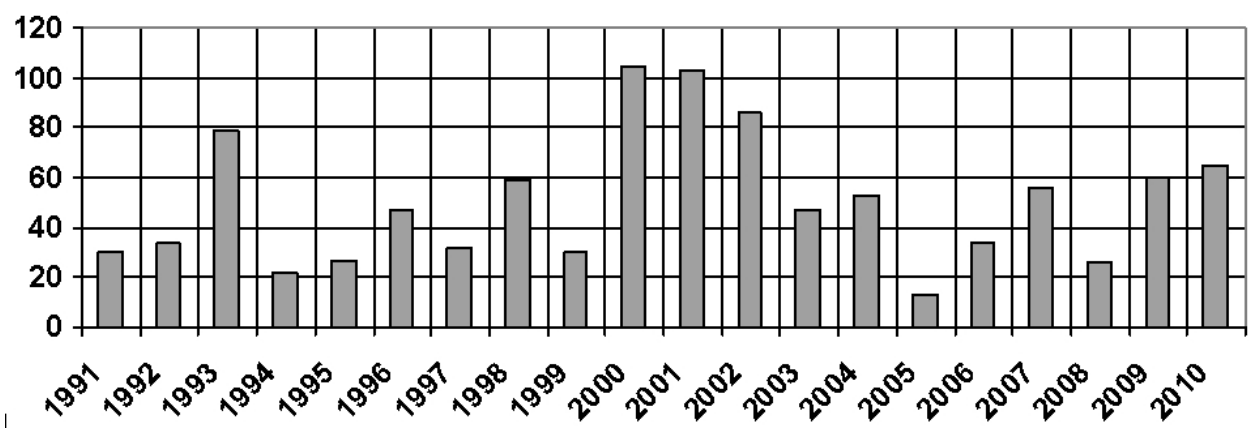

Figure 9. Number of fires in the municipality of Negotin, the period from 1991 to 2010

The dynamics of fire indicates the matching period for the largest number of fires during the month of August and July (Figure 7), which coincides with the period when the lowest number of cloudy days and a maximum of clear days was recorded.

Using correlation coefficients determined by the connection between the examined parameters, it was registered that in the period surveyed a slight positive trend of yearly number of fires was registered, Figure 10.

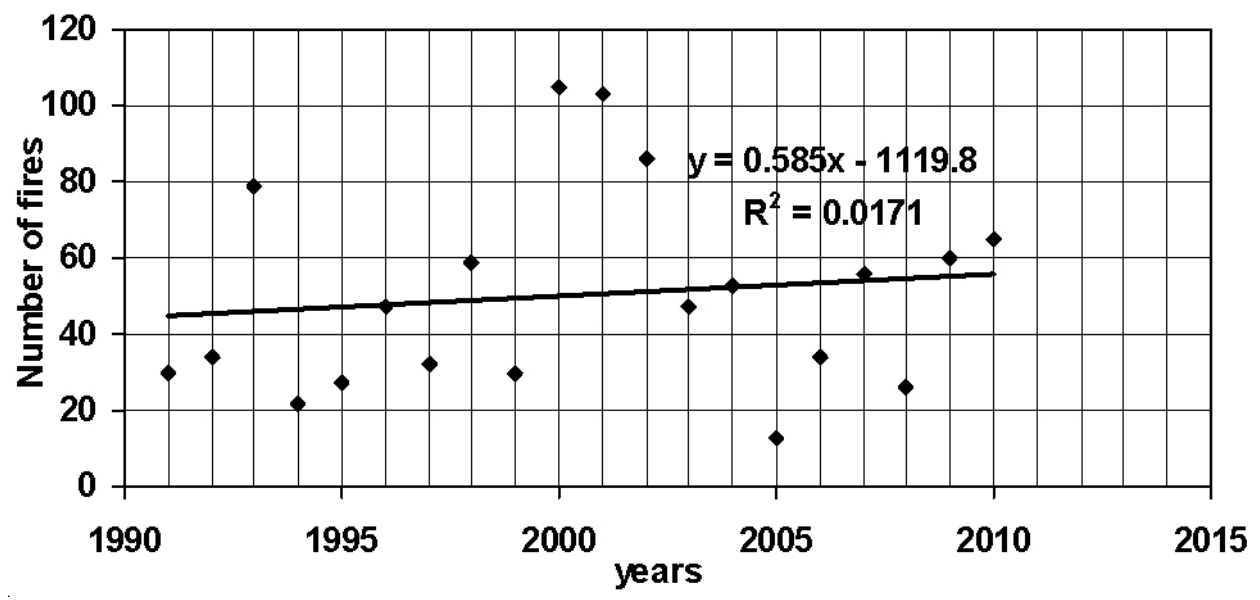

Figure 10. Trend number of fires in Negotin in the period from 1991 to 2010

The figures 11,12 and 13 are shown in the linear correlation of the annual number of fires with the parameters of cloudiness explored in the area of Negotin for the period 1991-2010. years. 


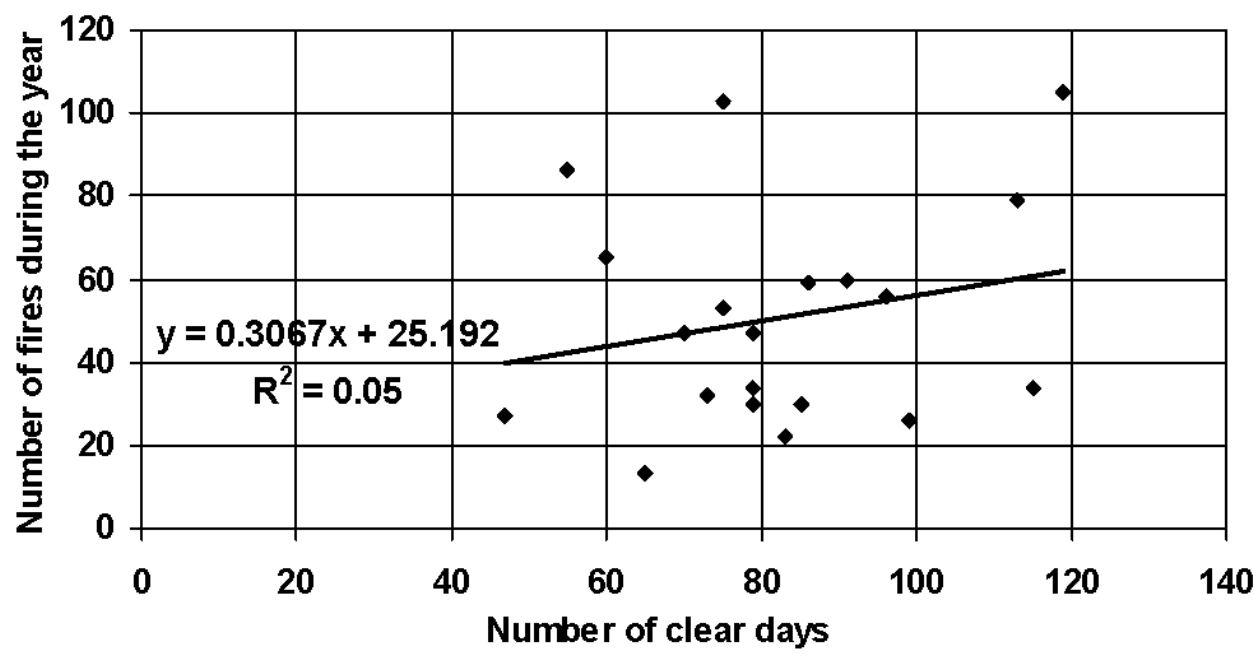

Figure 11. Linear correlation between the number of fires during the year and the number of clear days in Negotin for the period 1991-2010

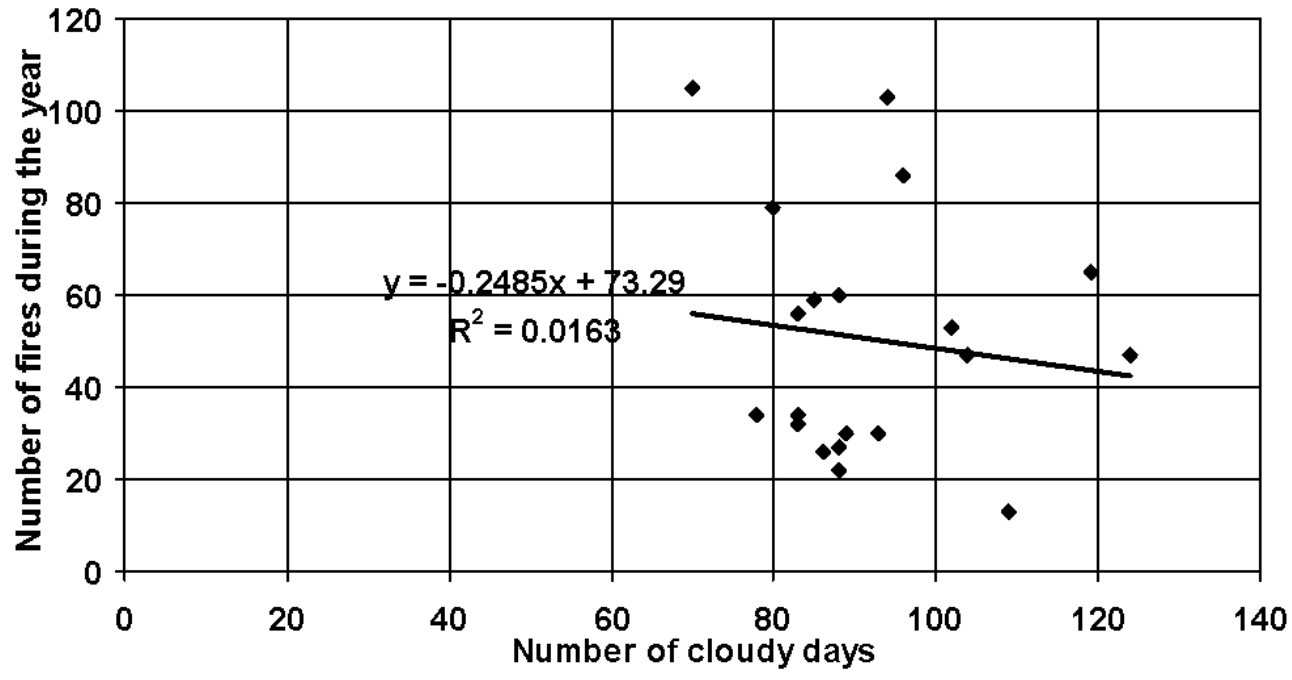

Figure 12. Linear correlation between the number of fires during the year and the number of cloudy days in Negotin for the period 1991-2010 


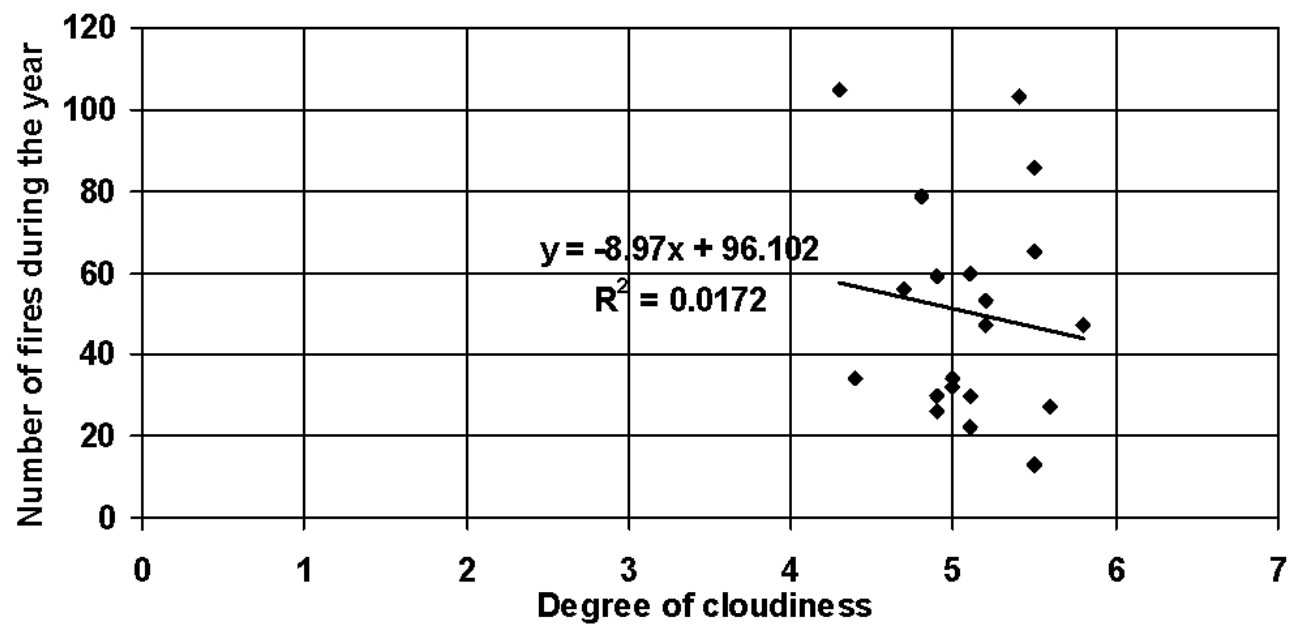

Figure 13. Linear correlation number of fires during the year and the degree of cloudiness in Negotin for the period 1991-2010

Figures 11, 12 and 13 show that there is a correlation between the cloudiness and occurrence of fire in a forests in the reporting period. On the basis of the value of Spearman's correlation coefficient it was concluded that the annual number of fires adversely correlates, with medium intensity, with the average number of cloudy days $(\rho=-0.26)$, but not statistically significantly $(p>0.05)$. The annual number of fire occurrences correlates positively with the average number of clear days $(\rho=0.25)$, but also not statistically significant.

\section{Conclusion}

Cloudiness is an important element of the climate, because it has a very important role in the global hydrological cycle and energy.

Characteristics of cloudiness, less cloudy and more sunny days, have an impact on the level of risk of forest fires during the year, due to rapid heating and drying moisture of combustible materials. The correlation between the number of fires and the number of clear days is relatively weak and positive. At the annual level, the highest number of fire occurrence was in year 2000, which is associated with at least a high cloudiness (4.3 tenths) and the total number of cloudy days (70) and the number of clear days (119).

Development of cloudiness visually indicates the physical processes taking place in the atmosphere, which can be used for predicting the possible weather development. Data on the cloudiness development may indicate to relevant services the need for taking measures to prevent and extinguish fires. 


\section{References}

Badescu V. Gueymard C. Cheva, S. Oprea C. Baciu M. Dumitrescu A. Iacobescu F. Milos I. Rada C. (2012): Computing global and diffuse solar hourly irradiation on clear sky. Review and testing of 54 models. Renewable and Sustainable Energy Reviews 16:3, 1636-1656.

Badescu V. Gueymard C. Cheval S. Oprea C. Baciu M. Dumitrescu A. Iacobescu F. Milos I. Rada C. (2013): Accuracy and sensitivity analysis for 54 models of computing hourly diffuse solar irradiation on clear sky. Theoretical and Applied Climatology 111:3-4, 379-399.

Badescu V. Dumitrescu A. (2015): Simple solar radiation modelling for different cloud types and climatologies, Theor. Appl. Climatol., p 1-20, DOI: 10.1007/s00704-0151400-7.

Borchert H. (2005): Changes of climate and air pollution in Central Europe in correlation with changes of sun activities, Proceedings of the Third International Symposium on Air Quality Management at Urban, Regional and Global Scales., Istanbul - Turkey.

Chevallier F. Bauer P. Kelly G. Jakob C. McNally T. (2001): Model clouds over oceans as seen from space: Comparison with HIRS/2 and MSU radiances. Journal of Climate, 14, 4216-4229.

Das P. Doblas-Reyes J. Garcia A, Hansen J. Mariani L. Nain A. Kulasekaran R. Rathore S. Venkataraman S. (2010): Weather and Climate Forecasts for Agriculture. Guide to Agricultural Meteorological Practices (GAMP) 2010 Edition (WMO-No.134), Updated in 2012.

Falayi O. Rabiu B. (2011): Estimation of global solar radiation using cloud cover and surface temperature in some selected cities in Nigeria, Arch. Phy. Res., 2 (3):99109.

Fritz S. (1957): Solar energy on clear and cloudy days. Sci Monthly ;84:55 \pm 6 .

Handler C. Cheney P. Thomas L. Williams D. (1983): Forest Fire Behaviour and Effectes, Fire in Forestry, Vol. 1, John Wiley, New York, p.450.

Hourwitz B. (1945): Insolation in relation to cloudiness and cloud density. J Met 2: pp. 154-156.

Jakob C. (1999): Cloud Cover in the ECMWF Reanalysis, J. Clim., 12, 947-959

Kapeller L. (1959): SONNE, WOLKEN UND WIND - Das Buch der Meteorologie, Safari - Verlag, Berlin.

Kimura K. Stephenson G. (1969): Solar radiation on cloudy days, ASHRAE Transaction, Vol. 75, 227-234.

Kreith F. (1973): Principles of heat transfer. International Text Book Company, Scranton, Pennsylvania.

Lecina-Diaz J. Alvarez A. Retana J. (2014): Extreme Fire Severity Patterns in Topographic, Convective and Wind-Driven Historical Wildfires of Mediterranean Pine Forests, PLoS One v.9(1).

Milosavljević M. (1990): Klimatologija, Naučna knjiga Beograd, X izdanje, p 261. 
Morcrette J. (1991): Radiation and cloud radiative properties in the European Centre for Medium Range Weather Forecasts forecasting system, J. Geophys. Res., 96D, 91219132.

Otorepec S. (1980): Agrometeorologija, Nolit, Beograd, pp. 231.

***: URL:http:/www.hidmet.gov.rs/, 15.05.2015. Meteorological Yearbook 1961-2010. Belgrade

Spena A. D'Angiolini G, Strat, C. (2010): Correlations for a Mediterranean cloud cover model, Proc. SPIE 7773, Reliability of Photovoltaic Cells, Modules, Components, and Systems III, 77730V; doi:10.1117/12.859839; http://dx.doi.org/10.1117/12.859839

SPSS Software, version 15.

Supit I. van Kappel R. (1998): A simple method to estimate global radiation, Solar Energy, 63, 147-160.

Tahas V. Ristoiu D, Cosma C. (2011): Analysis of global solar radiation and precipitation trends in Cluj-Napoca, Romania, over the period 1921-2009. Carpath J Earth Env, 6 (2) (2011), pp. 289-302.

Ćurić M, Živanović S. (2013): Dependence between Deficit and Surplus of Precipitation and Forest Fires, Disaster Advances, 6(6), 64-69

Živanović S. (2010): Risk factors for forest fires, Bezbednost Beograd, 52, 179-190.

Živanović S. Jovanović D. Pešić D, Zigar D. (2011): The influence of precipitation on vulnerability of forest fires in the region of Negotin, Šumarstvo, Beograd,1-2, 125134 


\title{
MONITORING OBLAČNOSTI U FUNKCIJI ZAŠTITE ŠUMA OD POŽARA
}

\author{
Stanimir ŽIVANOVIĆ ${ }^{1}$, Darko ZIGAR ${ }^{2}$ \\ ${ }^{1}$ Emergency Management Sector of Serbia, Belgrade, Serbia, \\ ${ }^{2}$ University of Niš, Faculty of Occupational Safety in Niš, Čarnojevića10a, \\ 18000 Niš, Serbia \\ Corresponding author: e-mail: zivannn@mts.rs
}

\begin{abstract}
REZIME
Požari u šumi su sezonskog karaktera, uslovljeni sadržajem vlage u gorivom materijalu. Pojava ovih požara u Srbiji je sve učestalija, a zavisno o intenzitetu i trajanju imaju veliki uticaj na stanje vegetacije. Cilj rada je bio da se utvrdi povezanost između hoda oblačnosti i dinamike pojave šumskih požara. Za istraživanje povezanosti ispitivanih svojstava korišteni su Pirsonovi koeficijenti korelacije. Analiza je bazirana na meteorološkim podacima dobijenih sa meteorološke stanice Negotin za period od 1991. do 2010. godine. Između ispitivanih uticaja, stepen oblačnosti je pokazao pozitivnu korelativnu međuzavisnost sa dinamikom pojave požara u prirodi. Godišnji broj požara koreliše pozitivno sa prosečnim brojem vedrih dana $(\rho=0.25)$. Takođe, utvrđeno je da godišnji broj požara negativno, srednjim intenzitetom, koreliše sa prosečnim brojem oblačnih dana $(\rho=-0.26)$, ali ne i statistički značajno ( $p>$ $0.05)$.
\end{abstract}

Ključne reči: oblačnost, šumski požar, koeficijent korelacije 